\title{
The Effect of Work Motivation and Discipline on Employee Productivity at PT. Anugerah Agung in Jakarta
}

\author{
Sutrisno $^{1}$, Denok Sunarsi ${ }^{2}$ \\ Univesitas Pamulang \\ E-mail: dosen00035@unpam.ac.id ${ }^{1}, \underline{\text { denoksunarsi@unpam.ac.id }{ }^{2}}$
}

(Received: July-2019; revised: August-2019; published: December-2019)

\begin{abstract}
This study aims to determine the effect of motivation and work discipline on employee productivity at PT. Anugerah Agung in Jakarta. The method used was explanatory research with a sample of 85 respondents. The analysis technique uses statistical analysis with regression testing, correlation, determination and hypothesis testing. The results of this study have a significant effect on employee productivity by $48.6 \%$, hypothesis testing obtained significance $0,000<0.05$. Work discipline has a significant effect on employee productivity by $44.6 \%$, hypothesis testing obtained significance of $0,000<0.05$. Motivation and work discipline simultaneously have a significant effect on employee productivity by $56.2 \%$, hypothesis testing obtained significance of $0,000<0.05$.
\end{abstract}

Keywords: Motivation; Work discipline; Employee productivity.

\section{INTRODUCTION}

As In building a company, competent human resources (HR) are needed who are able to carry out the company's strategies well to achieve the stated goals (Lamangida et al., 2017; Nasrullah et al., 2017; Niswaty et al., 2016; M. S. Saggaf et al., 2018; S. Saggaf et al., 2014; Sunarsi, 2017). Humans are important resources in industry and organizations, therefore human resource management includes providing qualified labor, maintaining quality and controlling labor costs (Chams \& García-Blandón, 2019; Lopez-Cabrales \& Valle-Cabrera, 2019; Oelze \& Habisch, 2018). The explanation is clear that the existence of HR is the most important asset for the company, because its existence is considered as the driving force and implementing the company's policies in achieving the stated goals.

So that companies can compete, the demand for awareness of the importance of the quality of human resources (HR) which is one of the responses in addressing these changes is very important. Quality human resources (HR) is very important for a company. Even the availability of quality human resources is believed to be the main key to success. Therefore, to realize quality human resources, the need for optimal participation from the company itself as a forum for development for the HR itself (HR investment). Human resource management is the key to achieving an organization's competitive advantage (Lobanova \& Ozolina-Ozola, 2014; Shahzad et al., 2016; Zaid et al., 2018; Zehir et al., 2016; Zhao \& Du, 2012). Explanation of the Greer theory shows that HR has a very important role compared to other than the company. 
188| Jurnal Administrare: Jurnal Pemikiran Ilmiah dan Pendidikan Administrasi Perkantoran

Volume 6 No. 2 July - December 2019. Pages 187-196

someone The existence of HR as the center of various company activities, running a business, controlling and evaluating even delivering the company to the pinnacle of success.

PT. Anugerah is a company engaged in cosmetics sales where the largest market share is in the country. It should show productivity that is optimal in an effort to realize predetermined goals. One aspect that drives the achievement of high work productivity is motivation. Motivation is a condition that moves employees to be able to achieve their goals and motives (Sunarsi, 2014, 2017, 2018a, 2018b, 2016). Employee motivation can be influenced by factors of interest, salary received, needs will feel secure, interpersonal relationships and opportunities to work. Even if an employee has good operational skills, if he does not have the motivation to work, then the final results or productivity results will be unproductive and will not be satisfactory (Astuti et al., 2016; Nasrullah et al., 2017; Wijaya et al., 2018).

Besides motivation, one thing that must be considered to increase company output is work discipline. To achieve the company's goals, an employee's work discipline is needed so that the work productivity of each employee can be increased, which in turn employee productivity will increase as well, the employee's work discipline will maintain their mental attitude and character to increasingly realize or understand the duties and responsibilities in their work. A person's awareness and willingness to obey all company regulations and applicable social norms. Mental attitudes of employees need to be fostered continuously, because the growth of mental attitude of discipline will greatly help the company in achieving maximum output.

The best employee work discipline must be instilled in every employee, on the contrary not on coercion or demand but based on awareness from within each employee to get good work discipline employees must obey strict rules, obey company regulations, obey to the rules of conduct at work and to obey other rules.

Increasing motivation and work discipline will result in a good level of productivity. Therefore leaders must be able to provide motivation and discipline to their employees, in order to increase employee productivity in the company and the employees are aware of their obligations to carry out the tasks assigned. This is in line with Sutrisno (2017) opinion that "Productivity is the relationship between output (goods or services) and inputs (labor, materials, money"). Based on the above background, the authors are interested in researching with the title: "The Effect of Work Motivation and Work Discipline on Employee Productivity"

\section{METHOD}

The method used is explanatory research (Creswell \& Creswell, 2017). The population in this study amounted to 85 respondents PT. Anugerah Agung in Jakarta. The sampling technique in this study is saturated sampling, where all members of the population are sampled. Thus the sample in this study amounted to 85 respondents. In analyzing the data used the instrument test, classical assumption test, regression, coefficient of determination and hypothesis testing. 


\section{RESULT AND DISCUSSION}

\section{Descriptive Analysis}

In this test used to determine the minimum and maximum scores, mean scores and standard deviations of each variable. The results are as follows:

Table 1.

Results of Descriptive Statistics Analysis

Descriptive Statistics

\begin{tabular}{|l|r|r|r|r|r}
\hline & N & Minimum & Maximum & The mean & Std. Deviation \\
\hline Motivation (X1) & 35 & 31 & 48 & 39.37 & 3,797 \\
\hline Work Discipline (X2) & 35 & 31 & 46 & 38.89 & 4,129 \\
\hline Employee Productivity (Y) & 35 & 31 & 48 & 39.20 & 3,604 \\
\hline Valid N (listwise) & 35 & & & & \\
\hline
\end{tabular}

Motivation obtained a minimum variance of 31 and a maximum variance of 48 with a mean score of 3.94 with a standard deviation of 3.797. Work discipline obtained a minimum variance of 31 and a maximum variance of 46 with a mean score of 3.89 with a standard deviation of 4.129. Employee productivity obtained a minimum variance of 31 and a maximum variance of 48 with a mean score of 3.92 with a standard deviation of 3.604 .

\section{Verification Analysis}

This analysis is intended to determine the effect of independent variables on the dependent variable. The test results are as follows:

\section{Multiple Linear Regression Analysis}

This regression test is intended to determine changes in the dependent variable if the independent variable changes. The test results are as follows:

Table 2.

Results of Multiple Liner Regression Testing

\section{Coefficients $^{\text {a }}$}

\begin{tabular}{|c|c|c|c|c|c|c|}
\hline \multirow{2}{*}{\multicolumn{2}{|c|}{ Model }} & \multicolumn{2}{|c|}{$\begin{array}{c}\text { Unstandardized } \\
\text { Coefficients }\end{array}$} & \multirow{2}{*}{$\begin{array}{l}\text { Standardized } \\
\text { Coefficients } \\
\text { Beta }\end{array}$} & \multirow[b]{2}{*}{$\mathrm{t}$} & \multirow[b]{2}{*}{ Sig. } \\
\hline & & B & Std. Error & & & \\
\hline & (Constant) & 9,754 & 4,621 & & 2,111 & .043 \\
\hline & Motivation (X1) & .431 & .148 & .454 & 2,913 & .006 \\
\hline & Work Discipline (X2) & .321 & .136 & .367 & 2,354 & .025 \\
\hline
\end{tabular}

a. Dependent Variable: Employee Productivity (Y) 
Based on the test results in the table above, the regression equation $\mathrm{Y}=9,754+0,431 \mathrm{X} 1$ $+0,321 \mathrm{X} 2$ is obtained. From the equation explained as follows:

1) A constant of 9,754 means that if there is no motivation and work discipline, then there is an employee productivity value of 9,754 points.

2) Motivational regression coefficient of 0.431 , this number is positive meaning that every time there is an increase in motivation of 0.431 , employee productivity will also increase by 0.431 points.

3) The coefficient of work discipline regression is 0.321 , this number is positive meaning that every time there is an increase in work discipline by 0.321 , employee productivity will also increase by 0.321 points.

\section{Correlation Coefficient Analysis}

Correlation coefficient analysis is intended to determine the degree of relationship strength of the independent variables on the dependent variable either partially or simultaneously. The test results are as follows:

Table 3

Test Results for Motivation Correlation Coefficient on Employee Productivity.

\begin{tabular}{llr|r}
\hline & \multicolumn{1}{c}{ Correlations $^{\mathbf{b}}$} & \multicolumn{1}{c}{$\begin{array}{c}\text { Motivation } \\
\text { (X1) }\end{array}$} & $\begin{array}{c}\text { Employee } \\
\text { Productivity } \\
\text { (Y) }\end{array}$ \\
\hline Motivation (X1) & Pearson Correlation & 1 & $.697^{* *}$ \\
\cline { 2 - 4 } & Sig. (2-tailed) & .000 \\
\hline Employee Productivity (Y) & Pearson Correlation & $.697^{* *}$ & 1 \\
\cline { 2 - 4 } & Sig. (2-tailed) & .000 & \\
\hline
\end{tabular}

**. Correlation is significant at the 0.01 level (2-tailed).

b. Listwise $\mathrm{N}=35$

Based on the test results obtained by a correlation value of 0.697 means that motivation has a strong relationship to employee productivity.

Table 4.

Test Results for the Work Discipline Correlation Coefficient on Employee Productivity.

\section{Correlations $^{b}$}

\begin{tabular}{llr|r}
\hline & & \multicolumn{1}{c}{$\begin{array}{c}\text { Employee } \\
\text { Productivity (Y) }\end{array}$} \\
\hline Work Discipline (X2) & Pearson Correlation & 1 & $.668^{* *}$ \\
\cline { 2 - 4 } & Sig. (2-tailed) & & .000 \\
\hline $\begin{array}{l}\text { Employee Productivity } \\
\text { (Y) }\end{array}$ & Pearson Correlation & $.668^{* *}$ & 1 \\
\cline { 2 - 4 } & Sig. (2-tailed) & .000 & \\
\hline
\end{tabular}

**. Correlation is significant at the 0.01 level (2-tailed).

b. Listwise $\mathrm{N}=35$ 
Based on the test results obtained a correlation value of 0.668 means that work discipline has a strong relationship to employee productivity.

Table 5

Simultaneous Correlation Test Results of Work Motivation and Discipline Coefficient On Employee Productivity.

\begin{tabular}{lr|rrrr}
\multicolumn{6}{c}{ Summary Model } \\
\hline Model & R & R Square & Adjusted R Square & Std. Error of the Estimate \\
\hline 1 & $.750^{\mathrm{a}}$ & .562 & .535 & 2,458 \\
\hline
\end{tabular}

a. Predictors: (Constant), Work Discipline (X2), Motivation (X1)

Based on the test results obtained a correlation value of 0.750 means that motivation and work discipline simultaneously have a strong relationship to employee productivity.

\section{Analysis of the Coefficient of Determination}

Analysis of the coefficient of determination is intended to determine the percentage of influence of the independent variable on the dependent variable either partially or simultaneously. The test results are as follows:

Table 6.

Test Results for Motivation Determination Coefficient on Employee Productivity.

\section{Summary Model}

\begin{tabular}{lr|r|r|r}
\hline Model & R & \multicolumn{1}{c|}{ R Square } & Adjusted R Square & Std. Error of the Estimate \\
\hline 1 & $.697^{\mathrm{a}}$ & .486 & .471 & 2,622 \\
\hline
\end{tabular}

a. Predictors: (Constant), Motivation (X1)

Based on the test results obtained a determination value of 0.486 means that motivation has an influence contribution of $48.6 \%$ on employee productivity.

Table 7

Test Results for the Work Discipline Coefficient Determination of Employee Productivity.

\section{Summary Model}

\begin{tabular}{lr|r|r|r}
\hline Model & R & R Square & Adjusted R Square & Std. Error of the Estimate \\
\hline 1 & $.668^{\mathrm{a}}$ & .446 & .429 & 2,723 \\
\hline
\end{tabular}

a. Predictors: (Constant), Work Discipline (X2)

Based on the test results obtained a determination value of 0.446 means that work discipline has an influence contribution of $44.6 \%$ on employee productivity. 
192 Jurnal Administrare: Jurnal Pemikiran Ilmiah dan Pendidikan Administrasi Perkantoran

Volume 6 No. 2 July - December 2019. Pages 187-196

Table 8

Testing Results Coefficient Determination Motivation and Work Discipline Against Employee Productivity.

\section{Summary Model}

\begin{tabular}{lr|rrrr}
\hline Model & R & \multicolumn{1}{c}{ R Square } & Adjusted R Square & Std. Error of the Estimate \\
\hline 1 & $.750^{\mathrm{a}}$ & .562 & .535 & 2,458 \\
\hline
\end{tabular}

a. Predictors: (Constant), Work Discipline (X2), Motivation (X1)

Based on the test results obtained a determination value of 0.562 means that motivation and work discipline simultaneously have an influence contribution of $56.2 \%$ on employee productivity, while the remaining $43.8 \%$ is influenced by other factors.

\section{Hypothesis testing}

\section{Partial hypothesis test ( $t$ test)}

Hypothesis testing with $\mathrm{t}$ test is used to find out which partial hypotheses are accepted. productivity.

First Hypothesis: There is a significant influence between motivation on employee

Table 9

Motivation Hypothesis Test Results Against Employee Productivity.

\begin{tabular}{|c|c|c|c|c|c|}
\hline \multirow[b]{3}{*}{ Model } & \multirow{2}{*}{\multicolumn{2}{|c|}{$\begin{array}{l}\text { Unstandardized } \\
\text { Coefficients }\end{array}$}} & \multirow{3}{*}{$\begin{array}{c}\text { Standardized } \\
\text { Coefficients } \\
\text { Beta }\end{array}$} & \multirow[b]{3}{*}{$\mathrm{t}$} & \multirow[b]{3}{*}{ Sig. } \\
\hline & & & & & \\
\hline & $\mathrm{B}$ & Std. Error & & & \\
\hline $\begin{array}{ll}1 & \text { (Constant) }\end{array}$ & 13.144 & 4,684 & & 2,806 & .008 \\
\hline Motivation (X1) & .662 & .118 & .697 & 5,588 & .000 \\
\hline
\end{tabular}

a. Dependent Variable: Employee Productivity (Y)

Based on the test results in the above table, the value of $t$ count $>t$ table or $(5.588>2.035)$ is obtained, thus the first hypothesis proposed that there is a significant influence between motivation on employee productivity is received.

Table 10

Results of the Work Discipline Hypothesis Test on Employee Productivity.

Coefficients ${ }^{\text {a }}$

\begin{tabular}{|c|c|c|c|c|c|c|}
\hline \multirow{2}{*}{\multicolumn{2}{|c|}{ Model }} & \multicolumn{2}{|c|}{$\begin{array}{c}\text { Unstandardized } \\
\text { Coefficients }\end{array}$} & \multirow{2}{*}{$\begin{array}{l}\text { Standardized } \\
\text { Coefficients } \\
\text { Beta }\end{array}$} & \multirow[b]{2}{*}{$\mathrm{t}$} & \multirow[b]{2}{*}{ Sig. } \\
\hline & & $\mathrm{B}$ & Std. Error & & & \\
\hline & (Constant) & 16,535 & 4,423 & & 3,739 & .001 \\
\hline & Work Discipline (X2) & 583 & .113 & .688 & 5,153 & .000 \\
\hline
\end{tabular}

a. Dependent Variable: Employee Productivity (Y) 
Based on the test results in the above table, the value of $t$ count $>t$ table or (5.153>2.035) is obtained, thus the second hypothesis is proposed that there is a significant influence between work discipline on employee productivity received.

\section{Simultaneous Hypothesis Test (Test F)}

Hypothesis testing with the F test is used to find out which simultaneous hypotheses are accepted. The third hypothesis There is a significant influence between motivation and work discipline on employee productivity.

Table 11

Hypothesis Test Results Motivation and Work Discipline Against Employee Productivity.

ANOVA a

\begin{tabular}{|c|c|c|c|c|c|c|}
\hline \multicolumn{2}{|c|}{ Model } & Sum of Squares & $\mathrm{df}$ & Mean Square & $\mathrm{F}$ & Sig. \\
\hline \multirow[t]{3}{*}{1} & Regression & 248,196 & 2 & 124,098 & 20333 & $.000^{\mathrm{b}}$ \\
\hline & Residual & 193,404 & 32 & 6,044 & & \\
\hline & Total & 441,600 & 34 & & & \\
\hline
\end{tabular}

a. Dependent Variable: Employee Productivity (Y)

b. Predictors: (Constant), Work Discipline (X2), Motivation (X1)

Based on the test results in the above table, the calculated F value> F table or (20.533> 2,900 ), thus the third hypothesis proposed that there is a significant influence between motivation and work discipline on employee productivity is received.

\section{Discussion}

\section{Effect of Motivation on Employee Productivity}

Motivation has a significant effect on employee productivity with a correlation of 0.697 or has a strong relationship with an influence contribution of 48.6\%. Hypothesis testing obtained $\mathrm{t}$ count $>\mathrm{t}$ table or $(5.588>2.035)$. Thus the first hypothesis proposed that there is a significant effect between motivation on employee productivity is accepted.

\section{Effect of Work Discipline on Employee Productivity}

Work discipline has a significant effect on employee productivity with a correlation of 0.668 or has a strong relationship with an influence contribution of $44.6 \%$. Hypothesis testing obtained $t$ value $>t$ table or $(5.153>2.035)$. Thus the second hypothesis proposed that there is a significant effect between work discipline on employee productivity is accepted.

\section{Effect of Work Motivation and Discipline on Employee Productivity}

Motivation and work discipline have a significant effect on employee productivity by obtaining a regression equation $\mathrm{Y}=9,754+0,431 \mathrm{X} 1+0,321 \mathrm{X} 2$, a correlation value of 0,750 or 
having a strong relationship with a contributing effect of $56.2 \%$ while the remaining $43.8 \%$ is influenced by other factors. Hypothesis testing obtained F value> F table or (20.533> 2.900). Thus the third hypothesis proposed that there is a significant effect between motivation and work discipline on employee productivity is accepted.

\section{CONCLUSIONS}

Motivation has a significant effect on employee productivity with an influence contribution of $48.6 \%$. Hypothesis testing obtained $t$ count $>t$ table or (5.588> 2.035). Work discipline has a significant effect on employee productivity with an influence contribution of $44.6 \%$. Hypothesis testing obtained $t$ value $>t$ table or (5.153> 2.035). Motivation and work discipline have a significant effect on employee productivity with a contribution of $56.2 \%$ while the remaining $43.8 \%$ are influenced by other factors. Hypothesis testing obtained the value of $\mathrm{F}$ count> F table or $(20.533>2,900)$.

\section{REFERENCES}

Astuti, A., Saleh, S., Baharuddin, A., \& Salam, R. (2016). Studi Motivasi Kerja Pegawai pada PT. Bank Sulselbar Cabang Utama Makassar. JURNAL ILMU ADMINISTRASI PERKANTORAN (JIAP), 79-88.

Chams, N., \& García-Blandón, J. (2019). On the importance of sustainable human resource management for the adoption of sustainable development goals. Resources, Conservation and Recycling, 141, 109-122. https://doi.org/https://doi.org/10.1016/j.resconrec.2018.10.006

Creswell, J. W., \& Creswell, J. D. (2017). Research design: Qualitative, quantitative, and mixed methods approaches. Sage publications.

Lamangida, T., Akib, H., Akbar, M. F., \& Aswar, M. (2017). Actors' Role in Public Asset Management.

Lobanova, L., \& Ozolina-Ozola, I. (2014). Comparative Evaluation of the Practical Areas of Human Resource Management in Lithuania and Latvia. Procedia - Social and Behavioral Sciences, 110, 607-616. https://doi.org/https://doi.org/10.1016/j.sbspro.2013.12.905

Lopez-Cabrales, A., \& Valle-Cabrera, R. (2019). Sustainable HRM strategies and employment relationships as drivers of the triple bottom line. Human Resource Management Review, 100689. https://doi.org/https://doi.org/10.1016/j.hrmr.2019.100689

Nasrullah, M., Salam, R., Pratiwi, D., \& Niswaty, R. (2017). Motivasi Kerja Pegawai Di Kantor Keyahbandaran Utama Makassar. Jurnal Ilmiah Manajemen Dan Bisnis, 18(2), 206-211.

Niswaty, R., Darwis, M., Alimuddin, W., \& Salam, R. (2016). Pengaruh Penerapan Prinsip Good Governance terhadap Efektivitas Kerja Pegawai. Jurnal Ilmiah Administrasi Publik (JIAP), 95-100.

Oelze, N., \& Habisch, A. (2018). Responsible supply chain implementation - Are multinational 
Sutrisno, Denok Sunarsi; The Effect of Work Motivation and Discipline on Employee Productivity ... |195

companies gods and small and medium sized enterprises oxen? Journal of Cleaner Production, 179, 738-752. https://doi.org/https://doi.org/10.1016/j.jclepro.2017.10.134

Rialmi, Z., \& Morsen, M. (2020). Pengaruh Komunikasi Terhadap Kinerja Karyawan PT Utama Metal Abadi. JENIUS, 3(2), 221-227.

Rialmi, Z. (2017). Pengaruh Keadilan Prosedural Yang Diterapkan Kepemimpinan Pegawai Dan Kepuasan Kerja Pegawai Terhadap Kinerja Dari Pegawai BPBD Provinsi Riau. Jurnal Mandiri: Ilmu Pengetahuan, Seni, dan Teknologi, 1(2), 353-374.Rivai Veithzal (2015) Manajemen Sumber Daya Manusia Untuk Perusahaan. Jakarta: PT Raja Grafindo Persada.

Saggaf, M. S., Akib, H., Salam, R., Baharuddin, A., \& Kasmita, M. (2018). The Quality Analysis Of Academic Services.

Saggaf, S., Salam, R., Kahar, F., \& Akib, H. (2014). Pelayanan Fungsi Administrasi Perkantoran Modern. Jurnal Ad'ministrare, 1(1), 20-27.

Shahzad, K., Bajwa, S. U., Ansted, R. B., Mamoon, D., \& Khaliq-ur-Rehman. (2016). Evaluating human resource management capacity for effective implementation of advanced metering infrastructure by electricity distribution companies in Pakistan. Utilities Policy, 41, 107117. https://doi.org/https://doi.org/10.1016/j.jup.2016.06.011

Sunarsi, D. (2014). Pengaruh Gaya Kepemimpinan, Disiplin dan Motivasi Terhadap Kinerja. Tesis. Fakultas Ekonomi Universitas Pamulang.

Sunarsi, D. (2017). Pengaruh Disiplin, Motivasi, Dan Kompetensi Terhadap Prestasi Belajar (Studi Kasus Pada Mahasiswa Universitas Pamulang, Tangerang Selatan Tahun Akademik 2016-2017). Jurnal Mandiri: Ilmu Pengetahuan, Seni, Dan Teknologi, 1(2), 207-226.

Sunarsi, D. (2018a). Pengaruh Gaya Kepemimpinan, Motivasi Dan Disiplin Kerja Terhadap Kinerja Pendidik Yayasan Marvin. Inovasi, 5(1), 1-18.

Sunarsi, D. (2018b). Pengaruh Motivasi Dan Disiplin Terhadap Produktivitas Kerja Karyawan Pada PT. Nadi Suwarna Bumi. Jurnal Semarak, 1(1).

Sunarsi, D. (2016). Pengaruh Minat, Motivasi Dan Kecerdasan Kognitif Terhadap Prestasi Belajar (Studi Kasus Pada Mahasiswa Program Studi S-1 Manajemen. Fakultas Ekonomi. Universitas Pamulang. Thn. Akademik 2015-2016). Proceedings, 1(1).

Sutrisno, H. (2017). Pengaruh Proses Seleksi Terhadap Kinerja Karyawan Pada Pt Secure Parking Unit Summarecon Digital Center.

Wijaya, D. N., Sunarti, \& Pangestuti, E. (2018). Pengaruh Gaya Hidup dan Motivasi Terhadap Keputusan Pembelian (Survei pada Konsumen Starbucks, Kota Malang). Administrasi Bisnis.

Zaid, A. A., Jaaron, A. A. M., \& Talib Bon, A. (2018). The impact of green human resource management and green supply chain management practices on sustainable performance: An empirical study. Journal of Cleaner Production, 204, 965-979. https://doi.org/https://doi.org/10.1016/j.jclepro.2018.09.062

Zehir, C., Gurol, Y., Karaboga, T., \& Kole, M. (2016). Strategic Human Resource Management and Firm Performance: The Mediating Role of Entrepreneurial Orientation. Procedia - 
196| Jurnal Administrare: Jurnal Pemikiran Ilmiah dan Pendidikan Administrasi Perkantoran Volume 6 No. 2 July - December 2019. Pages 187-196

Social and Behavioral Sciences, 235, 372-381. https://doi.org/https://doi.org/10.1016/j.sbspro.2016.11.045

Zhao, S., \& Du, J. (2012). Thirty-two years of development of human resource management in China: Review and prospects. Human Resource Management Review, 22(3), 179-188. https://doi.org/https://doi.org/10.1016/j.hrmr.2012.02.001 